Ann. Biol. anim. Bioch. Biophys., I976, 16 (3), 307-3Ir.

\title{
OVARIAN FOLLICULAR DEVELOPMENT AND GONADOTROPHIN LEVELS DURING PREPUBERTAL LIFE IN THREE STRAINS OF RAT WITH DIFFERENT SENSITIVITY TO FSH
}

\author{
Marie-Madeleine de REVIERS and M. TERQUI \\ with the technical assistance of Odile Moulin \\ Station de Physiologie de la Reproduction, \\ Centre de Recherches de Tours, I. N.R. A., \\ Nouzilly, 37380 Monnaie (France)
}

Females of three strains of Wistar rats $(03,04$ and I2) bred in our laboratory show significantly different responses to exogenous FSH, in the Steelman-Pohley assay $(04>03>$ I2). The fertility and some ovarian parameters of these strains have been reported previously (MAUleon and PELLELIER, I964; MAULEON, I972; IAND et al., r974). The present study was undertaken to explain the differences in sensitivity to FSH. Strain 0.3 is considered as the reference strain as its fertility is comparable with that of other Wistar rats.

\section{MATERIALS AND METHODS}

Ovarian follicular population and atresia were studied quantitatively following the techniques described by de Reviers (1974).

Pituitary FSH and LH contents were measured respectively by the STEELMAN and Pohley (1953) and Parlow (196I) assays. Plasma FSH and LH levels were measured by the NIAMDD radioimmunoassay in groups of 5 to 8 females from different litters. Radioimmunoassay of oestrogen was performed according to the method described by Tergut and DeLouts (1975).

\section{QUANTITATIVE STUDY OF GROWING FOLIICLES}

Follicular development was studied quantitatively to test the hypothesis that interstrain differences in sensitivity to FSH were due to differences in the number of ovarian follicles. Ovaries were studied at 12,20 and 32 days after birth as these are important times in ovarian development in strain 03 (de REVIERS and MAULEON, I976). In this strain there are many small and medium-sized follicles at day I2 
(429); at day 20 , the number reaches a maximum ( 843 per ovary); by day 32 , the number is much smaller (325).

In the three strains, the ovarian follicular population has the same pattern of development (fig. I). However, there are fewer developing follicles in strain $\mathbf{I} 2$ than in the two other strains. At day 20, their number is 633 per ovary in strain 04 but only 328 in strain $\mathrm{I} 2$. No antral follicles are found in strain I2 at this age whereas there are twice as many in strain 04 as in 03 . By day 32 , the number of follicles is similar in the three strains.

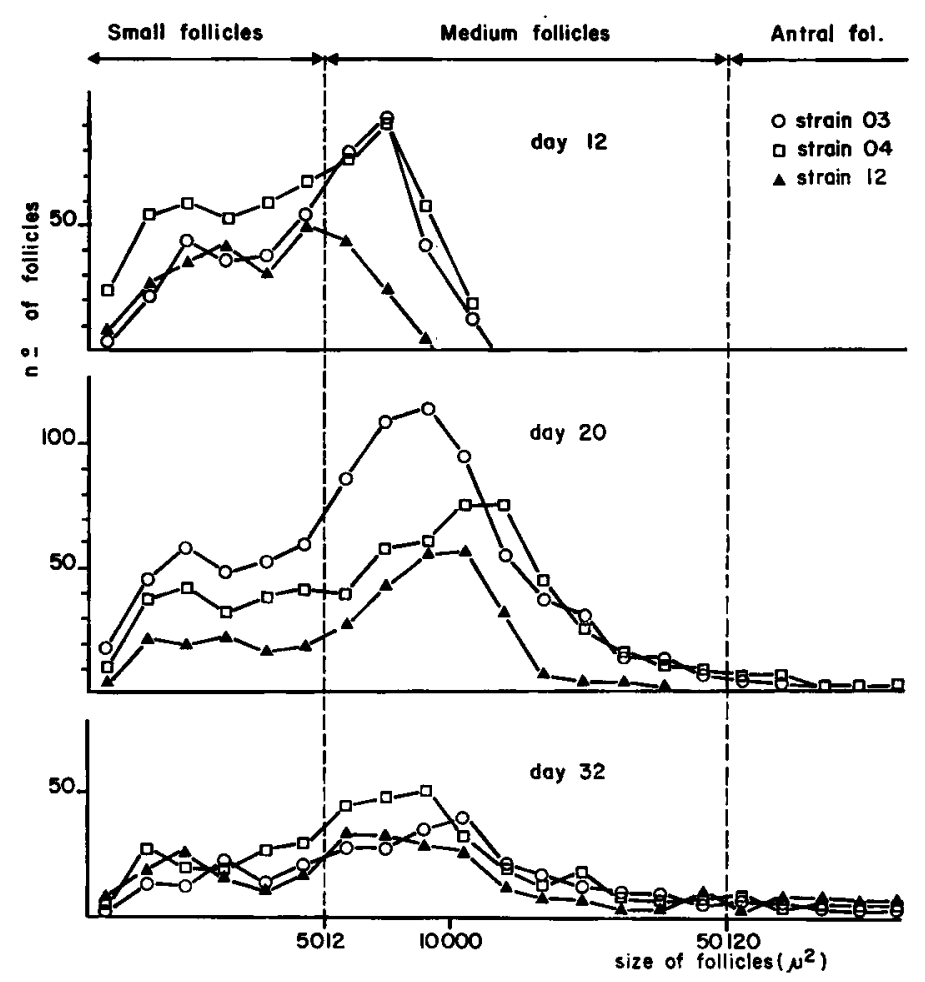

FIG. I. - Changes with age of normal follicle population in ovaries of three strains of rats

At birth, the number of oocytes is larger in strain I2 than in strain 03 (04 > I2 > 03) (LAND et al., I974). The small number of follicles which develop in strain I 2 could be due to atresia or to inadequate stimulation by gonadotrophic hormones.

\section{FOLIICULAR ATRESIA}

The ratio of the total volume occupied by normal and by atretic follicles was calculated. At day 20 , this ratio is nearly the same in the ovaries of the three strains of rat but it is lower at day 24 and 32 in strain 12 than in the two other strains. Thus, during this period, atresia is more marked in strain I2. But this does not explain the low number of normal follicles found at day 20 . 


\section{PITUITARY FSH AND LH}

The pituitary FSH and $\mathrm{I}_{1} \mathrm{H}$ levels were measured at days $12,16,20,24,28$ and 32 . The pattern of change in pituitary gonadotrophin coutent is the same in all three strains (fig. 2). FSH peaks at day 20 whereas the LH peak occurs at day 24 . However, the actual levels of the two hormones are different. The FSH peak level is highest in strain $\mathrm{O}_{4}\left(\mathrm{O}_{4}>\mathrm{I} 2>03\right)$ and the $\mathrm{LH}$ peak is highest in strain I2 (I2 $>04>03)$.

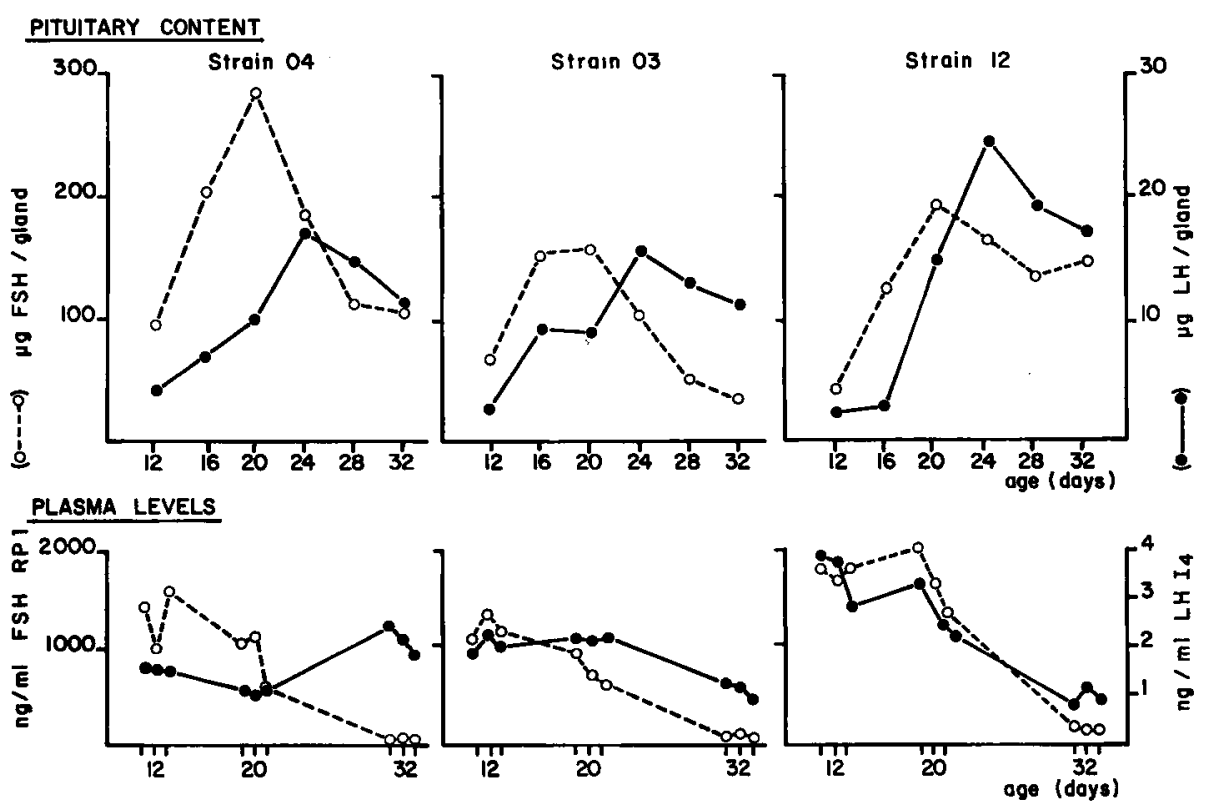

FIG. 2. - Pituitary contents,

plasma FSH and $L H$ levels in female rats of three strains during prepubertal life

\section{PLASMA LEVELS OF FSH, LH AND TOTAL OESTROGEN}

Radioimmunoassays of plasma FSH and LH were performed on days II, I2 and I3, I9, 20 and $2 I$ and $3 I, 32$ and 33 (fig. 2). FSH levels are very high at $I 2$ and 20 days in all three strains and low at day 32. However, FSH levels are higher in strain I2 $(12>04>03)$, the difference between strains 12 and 03 being statistically significant $(\mathrm{P}<0.0 \mathrm{I})$. LH levels are higher in strain I2 (I2 $>03>04$ ) $(\mathrm{P}<0.05$ strain $\mathrm{I} 2$ vs 04 ) at days $\mathrm{I} 2$ and 20.

Total oestrogen levels were measured at the same times. The levels are extremely high at day I2 ( 2 23I, I $59^{8}$ and 2 I 46 pg estrone/ml respectively in strains 03 , 04 and $\mathrm{I} 2)$ and day $20(3263,2859$ and $3359 \mathrm{pg}$ estrone/ml) and low at day 32 . Due to large individual variation the differences between strains are not significant. 


\section{DISCUSSION}

Though the onset of puberty (vaginal opening) occurs later in rats of strain I2 than in the two other strains (40-45 days $v s$ 32-38 days) it seems that FSH and I,H levels change in the same way in the three strains. As a matter of fact the peak levels of FSH and LH in the pituitary occur at the same time and the highest plasma levels occur at comparable times. These findings suggest that the general pattern of hypophyseal and ovarian development is similar in the three strains. However, the levels of gonadotrophic hormones are different and this may be responsible for the differences in ovarian follicular population.

High plasma levels of FSH and $\mathrm{LH}$ in strain $\mathbf{r} 2$ are not associated with an unusual degree of follicular development. Moreover, MAULEON (I972) has shown that at the $25^{\text {th }}$ day of postnatal life, the number of primordial follicles starting development is lower in strain I2 than in strain 03 (4 p. IOO vS II p. IO0). Thus, these high levels of FSH and LH seem to exert an inhibitory effect on follicular growth and to favour atresia. In the 04 strain, a high $\mathrm{FSH}$ level stimulates follicular growth and antral formation. However, the hormonal balance (low level of $\mathrm{LH}$ ) does not seem suitable for initiation of follicular growth This would explain the small proportion of growing follicles in strain 04 (6.3 p. IOO vs II.O p. IOO in strain 03) (MAULEON, I972). But, as the number of primordial follicles is higher in the 04 than in the 03 strain (693I vs 4I5I), the absolute number of follicles starting to grow is similar.

We cannot exclude the possibility that the observed differences in sensitivity to FSH in the Steelman Pohley assay might be due to differences in the FSH receptors. Further work is needed to elucidate these interstrain differences in FSH sensitivity.

Sexual Maturation 3rd Workshop August 31, september 3, 1975 .

\section{ACKNOWLEDGEMENTS}

The authors are thankful to NIAMDD for the gift of materials used for radioimmunoassays of rat $\mathrm{FSH}$ and $\mathrm{LH}$.

\section{RÉSUMMÉ}

DÉVELOPPEMENT DE LA POPULATION FOLLICULAIRE OVARIENNE ET NIVEAUX D'HORMONES GONADOTROPES CHEZ DES RATTES IMPUBÈRES APPARTENANT A TROIS SOUCHES DE SENSIBILITÉ A FSH DIFFÉRENTE

La population folliculaire ovarienne, les niveaux hypophysaires et plasmatiques de FSH et $\mathrm{LH}$ ont été mesurés chez des rattes âgées de 12,20 et 32 jours ; ces rattes appartiennent à trois souches $\left(0_{3}, \mathrm{O}_{4}\right.$ et I 2$)$ dont la sensibilité ovarienne à $\mathrm{FSH}$ exogène est différente $\left(\mathrm{O}_{4}>\mathrm{O}_{3}>\mathrm{I}_{2}\right)$. La souche o3 est considérée comme souche de référence car sa fertilité est normale. 
A 12 et 20 jours d'âge, le nombre total des follicules ovariens est plus faible chez les rattes de la souche I 2 ; le nombre des follicules à antrum trouvé à zo jours est plus grand chez les rattes de la souche 04. L'atrésie folliculaire est peu différente entre souches.

Le pic de FSH hypophysaire à 20 jours est plus élevé dans la souche $\mathrm{O}_{4}\left(\mathrm{O}_{4}>\mathrm{I}_{2}>\mathrm{O}_{3}\right)$ et celui de LH à 24 jours est plus élevé dans la souche I 2 ( $12>04>03$ ).

Chez les rattes de la souche $\mathrm{I} 2$, aux âges étudiés, les niveaux plasmatiques sont plus élevés en FSH $\left(\mathrm{I}_{2}>\mathrm{O}_{4}>\mathrm{O}_{3}\right)$ et en $\mathrm{LH}\left(\mathrm{I}_{2}>\mathrm{O}_{3}>\mathrm{O}_{4}\right)$.

Entre la naissance et la puberté, la fonction hypophysaire et la population ovarienne évoluent aux mêmes moments dans les trois souches : ce sont les niveaux des hormones gonadotropes et le nombre des follicules en croissance qui diffèrent. Les hauts niveaux de FSH et de LH trouvés dans la souche I 2 semblent être défavorables à l'initiation de la croissance folliculaire tandis que le niveau élevé en FSH de la souche o4 favorise surtout l'apparition de l'antrum.

\section{REFERENCES}

Land R. B., de Reviers M. M., Thompson R., Mauleon P., I974. Quantitative physiological studies of genetic variation in the ovarian activity of the rat. J. Reprod. Fert., 38, 29-39.

Mauleon P., 1972. Genetic differences in the number of germinal cells during oogenesis and in the establishment of folliculogenesis in the rat. J. Reprod. Fert., 31, 5 I I-5 r2 (Abstr.).

Mauleon P., Pelletier J., 1964. Variations génétiques du fonctionnement hypophysaire de trois souches de rates immatures. Relations avec la fertilité, Ann. Biol. anim. Bioch. Biophys., 4, 105-112.

Parlow A. F., I96r. In Human Pituitary Gonadotrophins, A. Albert Ed., Springfield Thomas, $300-310$.

REviERs (de) M. M., I974. Étude quantitative de l'action des hormones gonadotropes hypophysaires sur la population folliculaire de l'ovaire de ratte immature. Signification biologique du dosage de l'hormone folliculostimulante par le test de Steelman et Pohley. Thèse Univ. Tours.

Reviers (de) M. M., Maulton P., I976. The maturation of the ovarian population and hypophyseal gonadotrophins in the immature rat. Ann. Biol. anim. Bioch. Biophys. (in press).

Steelman S. L., Pohley F. P., 1953. Assay of the follicle stimulating hormone based on the augmentation with human chorionic gonadotrophin. Endocrinology, 53, 604-6r6.

Tergui M., Delouis C., 1975. Variations and effects of oestrogen during pregnancy and parturition in the ewe (submitted for publication). 